\section{University of New Hampshire}

Carsey School of Public Policy

\section{CARSEY RESEARCH}

National Issue Brief \#141

Spring 2019

\title{
Job Protection and Wage Replacement Key Factors in Take Up of Paid Family and Medical Leave Among Lower-Wage Workers
}

Kristin Smith

$\mathrm{L}$ egislators across the United States are discussing paid family and medical leave, which allows workers to take an extended number of weeks away from their jobs, with some wage replacement, to care for a seriously ill, injured, or disabled family member, or a new child, or to tend to one's own serious health condition. California, New Jersey, Rhode Island, and New York currently have public programs that provide workers' access to paid family and medical leave; Washington, Massachusetts, and the District of Columbia recently passed similar legislation and have begun implementing their programs. More than a dozen states, including New Hampshire, are debating how to create new programs, while others, like New Jersey, are broadening the reach of their programs to more workers.

At the federal level, the Family and Medical Insurance Leave (FAMILY) Act was introduced in the United States Congress in February 2019 (House Bill 1185/Senate Bill 463), with 163 House co-sponsors and 35 Senate co-sponsors at introduction. It would go beyond the Family and Medical Leave Act (FMLA) of 1993 by providing up to 12 weeks of paid leave at 66 percent of the workers' wage up to a cap (the FMLA guaranteed only unpaid leave) and covering all workers regardless of firm size or a worker's full- or part-time hours (FMLA eligibility is much less broad). It would be paid for by shared employee and employer payroll contributions, and provide protections against workplace retaliation. The FAMILY Act also covers self-employed workers in recognition of the changing nature of work and employment relationships. ${ }^{1}$

Broader access to robust paid family and medical leave is widely supported by the public. Eighty-four percent of American voters support a paid family and medical leave policy for all workers, ${ }^{2}$ as do eight in

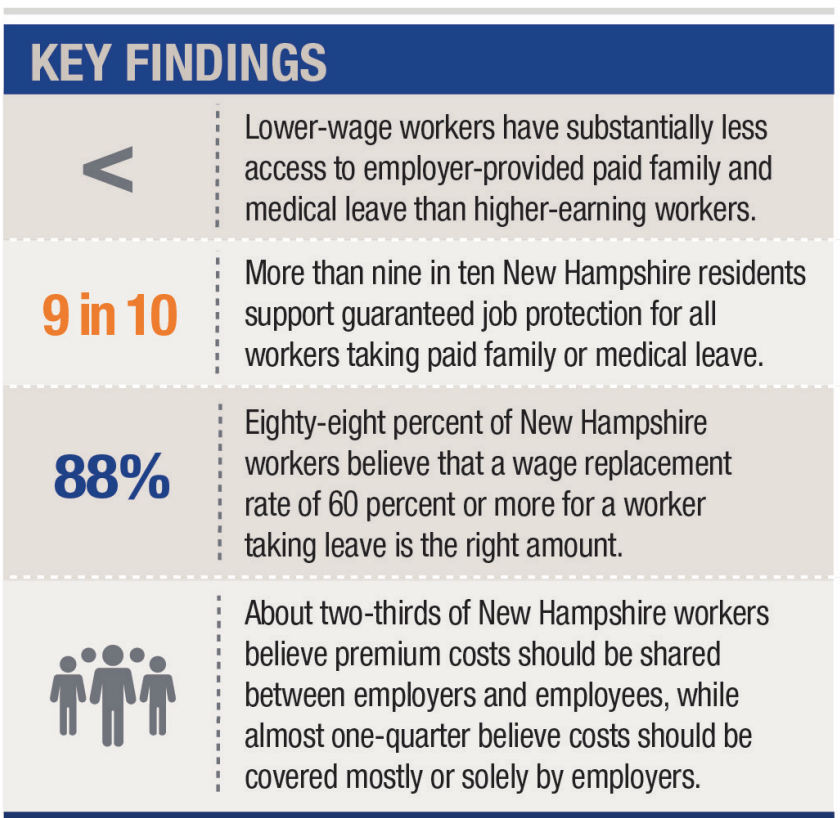

ten New Hampshire residents. ${ }^{3}$ Extensive support for a public program may be driven by the widespread lack of access to paid family and medical leave. ${ }^{4}$ In the absence of a public paid program, workers' access to paid leave depends on whether one's employer includes it as a workplace benefit. The result is vastly uneven access, with lower-wage workers, workers in smaller firms, and part-time workers having less access to paid family and medical leave than workers overall.

But even when lower-wage workers have access to paid leave, they are less likely to take it than are higher-wage workers, in large part because of the lack of job protection and low wage-replacement rates. ${ }^{5}$ Understanding how job protection and wage replacement rates are related to the use of paid family and medical leave among lower-wage workers is important for policymakers and stakeholders when considering paid leave policies. 


\section{Lower-Wage Earners} Lack Access to EmployerProvided Paid Family and Medical Leave

Nationally, 17 percent of workers have access to paid family leave through their employers. The gap between the highest- and lowest-wage workers is dramatic: among the highest decile of wage earners (people paid an average of $\$ 47.78$ per hour), 30 percent have access to employer-provided paid family leave, while the share at the lowest decile (people paid an average of $\$ 10.28$ per hour) is 5 percent. $^{6}$ Access to employer-provided shortterm disability insurance that provides partial wage replacement during a medical leave for a worker's own serious health issue follows the same disparate pattern by wage level. ${ }^{7}$

Inequities in access to paid family and medical leave in New Hampshire are similar. According to Granite State Poll data collected in New Hampshire in October 2018, about one-third of New Hampshire workers lack access to paid leave to tend to their own illness, over onehalf lack access to parental leave to care for a new child, and about two-thirds lack access to care for an ill family member (Table 1). Overall, less than a third of New Hampshire workers have access to paid leave for all three of these family and medical needs. The lack of paid leave for family care puts workers in a bind, forcing them to choose between receiving a paycheck and meeting family care responsibilities.

Whether workers have access to paid family and medical leave varies with earnings. Workers who earn $\$ 600$ or less per week, or about $\$ 15$ per hour for 40 hours per week,

\section{TABLE 1. PERCENT OF NEW HAMPSHIRE WORKERS LACKING ACCESS TO} PAID FAMILY AND MEDICAL LEAVE, 2018

\begin{tabular}{|c|c|c|c|c|}
\hline & $\begin{array}{l}\text { OWN } \\
\text { ILLNESS }\end{array}$ & $\begin{array}{l}\text { PARENTAL } \\
\text { LEAVE }\end{array}$ & $\begin{array}{c}\text { FAMILY } \\
\text { CARE }\end{array}$ & $\begin{array}{l}\text { ALL THREE } \\
\text { LEAVE TYPES }\end{array}$ \\
\hline All & 35 & 56 & 63 & 69 \\
\hline \multicolumn{5}{|l|}{ Weekly earnings quartiles } \\
\hline$\$ 600$ or less & 51 & 87 & 72 & 91 \\
\hline$\$ 601-\$ 1,000$ & $32^{a}$ & $48^{a}$ & 59 & $63^{a}$ \\
\hline$\$ 1,001-\$ 1,600$ & $22^{\mathrm{a}}$ & $57^{a, b}$ & 64 & $72^{a, b}$ \\
\hline More than $\$ 1,600$ & $15^{\mathrm{a}}$ & $32^{a}$ & $47^{a}$ & $49^{a}$ \\
\hline \multicolumn{5}{|l|}{ Firm size } \\
\hline Fewer than 50 employees & $58^{c}$ & $78^{c}$ & $83^{c}$ & $87^{c}$ \\
\hline 50 or more employees & 21 & 44 & 51 & 75 \\
\hline
\end{tabular}

Note: Estimates not shown for respondents missing on weekly earnings or firm size. ${ }^{\text {a }}$ statistically significant difference from $\$ 600$ or less at $p>.05$; $^{b}$ statistically significant difference from more than $\$ 1,600$ at $p>.05$; ${ }^{c}$ statistically significant difference from 50 or more employees at $p>05$.

Source: Granite State Poll, Paid Family and Medical Leave Topical Module, 2018.

have much less access to paid leave for their own illness and for parental leave than those with higher incomes (Table 1).

There is a clear delineation in access to paid leave between workers employed in firms with fewer than 50 employees and firms with more: employees working in smaller firms have lower access.

Workers in New Hampshire are not unique in their lack of access to paid family and medical leave, as these patterns are typical in states without a public-paid family and medical leave program.

\section{Job Protection Promotes Leave-Taking Among Lower-Wage Workers}

Access to paid leave without job protection may be a barrier to workers' use of paid leave even when paid leave is available. Research shows that job protection makes a substantial difference in the security workers feel in actually taking leave. Studies have shown that workers with access to leave may choose to not take it out of fear that they will lose their jobs, be demoted, or be passed over for promotions. ${ }^{8}$ This is particularly salient for lower-earning workers because they are less likely to have job-protected leave. Though the FMLA requires eligible workers be allowed to take up to 12 weeks of leave, paid or unpaid, for family and medical reasons within a 12 -month period, to be eligible employees must work for an employer with 50 or more workers and have worked 1,250 hours for the same employer over the previous year. These eligibility requirements disproportionately exclude lower-wage workers, who are more likely to work in small firms, work part-time hours, and have higher turnover between employers. ${ }^{9}$

New Hampshire residents are strongly supportive of paid leave with guaranteed job protection. More than nine in ten New Hampshire residents support guaranteed job protection for all workers taking paid leave (Table 2). This support is consistent across age, education, marital status, gender, employment status, and employer's firm size. ${ }^{10}$ Every earnings quartile registers support of 87 percent or higher. 


\section{TABLE 2. SUPPORT FOR GUARANTEED JOB PROTECTION FOR ALL WORKERS TAKING PAID FAMILY AND MEDICAL LEAVE, 2018}

\begin{tabular}{lc} 
& $\begin{array}{c}\text { SUPPORT FOR } \\
\text { JOB PROTECTION }\end{array}$ \\
\hline All & $93 \%$ \\
Weekly earnings quartiles & \\
$\$ 600$ or less & $94 \%$ \\
$\$ 601-\$ 1,000$ & $96 \%$ \\
$\$ 1,001-\$ 1,600$ & $99 \%^{\mathrm{a}}$ \\
More than $\$ 1,600$ & $87 \%$ \\
Firm size & \\
Fewer than 50 employees & $92 \%$ \\
50 or more employees & $93 \%$ \\
Political ideology & \\
Liberal & $98 \% \mathrm{~b}$ \\
Moderate & $98 \%{ }^{\mathrm{b}}$ \\
Conservative & $84 \%$ \\
\hline
\end{tabular}

Note: Support includes those who strongly or somewhat support guaranteed job protection. ${ }^{2}$ statistically significant difference from more than $\$ 1600$ at $\mathrm{p}>.05 ;{ }^{b}$ statistically significant difference from conservative ideology at $p>.05$.

Source: Granite State Poll, Paid Family and Medical Leave Topical Module, 2018.

Support for job protection varies somewhat by political ideology. Nearly all-98 percent—of those with a moderate or liberal political ideology are supportive of guaranteed job protection. Those with a conservative political ideology are less supportive, yet 84 percent report support.

California, New Jersey, New York, Rhode Island, and Washington incorporate the FMLA or state FMLA laws and guarantee job protection to workers at firms with 50 or more employees for leave for their own health reasons, but guarantee job protection for parental leave or family care leave to workers in smaller firms. Aware of the role that job protection plays in promoting leave taking, the Massachusetts program will guarantee job protection for all workers, and an improvement to New Jersey's program will expand job protection in June 2019 to workers in firms with
30 or more employees, rather than the 50-employee threshold previously in place. As proposed, the FAMILY Act provides job protection for workers in firms with 50 or more employees through the FMLA, but includes antiretaliation protections for all workers; this is an area lawmakers may investigate as they consider the bill and evidence from the states.

\section{The Wage Replacement}

\section{Rate Is a Key Factor} in Increasing Take-Up Rates Among LowerWage Earners

Having access to paid leave increases leave-taking among lower-wage workers. Evidence from California, where a statewide paid family leave program was implemented in 2004, shows that when the option for taking paid leave with partial wage replacement was provided, leavetaking rates doubled and average leave-taking duration increased by about five weeks among eligible new mothers. ${ }^{11}$ Economically vulnerable mothers realized the most gains. ${ }^{12}$

However, despite gains in leavetaking after a paid family leave program was introduced, disparities continue to exist in leave-taking among lower- and higher-wage workers. Analysis of existing programs shows that insufficient wage replacement may be a barrier to taking leave for lower-wage workers even when paid leave is available, because these workers may feel that they still cannot afford to take time off for an extended period. ${ }^{13}$ Within the context of a paid family and medical leave program, this obstacle to leave-taking creates a system that lower-wage workers pay into but cannot afford to fully use.

When asked about wage replacement rates while on paid leave, 60 percent of New Hampshire workers said that a 60 percent reimbursement rate was just about right, 28 percent said a higher rate was needed, and 12 percent said less was needed (Figure 1). ${ }^{14} \mathrm{~A}$ higher proportion of workers in larger firms said that more than 60 percent wage replacement was needed compared with their
FIGURE 1. WHAT WAGE REPLACEMENT RATE SHOULD BE PROVIDED?

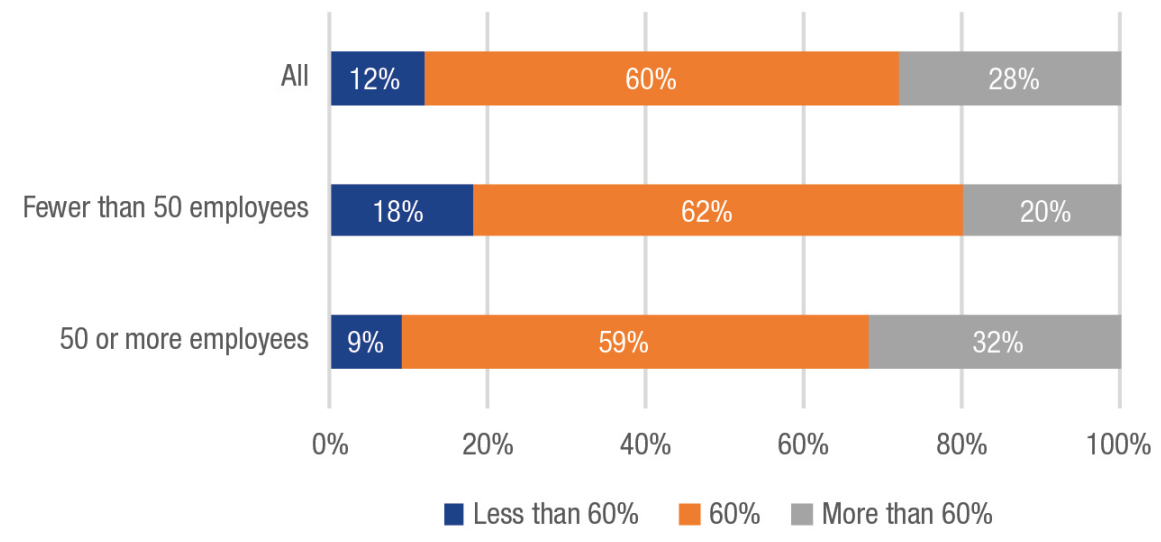

Note: Statistically significant difference between more than $60 \%$ by firm size at $p>.05$. Source: Granite State Poll, Paid Family and Medical Leave Topical Module, 2018. 
counterparts in firms with fewer than 50 employees, but the vast majority of workers in both groups agreed that at least 60 percent was needed (91 percent and 82 percent, respectively).

Let's consider what a 60 percent replacement rate looks like for a lower-wage worker earning $\$ 10$ per hour, or $\$ 400$ per week if he or she is working 40 hours per week. ${ }^{15}$ While on leave, a 60 percent replacement rate would provide that worker just $\$ 240$ per week, the equivalent of $\$ 6$ an hour, or less than the federal minimum wage of $\$ 7.25$. This rate is not very tenable over a twelve- or even six-week leave for a worker already struggling to make ends meet.

Even with a replacement rate of 70 percent, a full-time worker earning $\$ 400$ per week would receive an equivalent of $\$ 7$ per hour while on leave. It would take a replacement rate of 73 percent to bring that worker to just over the minimum wage.

In 2016, California raised its reimbursement rate from 55 percent to 70 percent for low-wage workers and 60 percent for all other workers, based

\section{FIGURE 2. WHO SHOULD PAY FOR A PAID FAMILY AND MEDICAL LEAVE PROGRAM?}

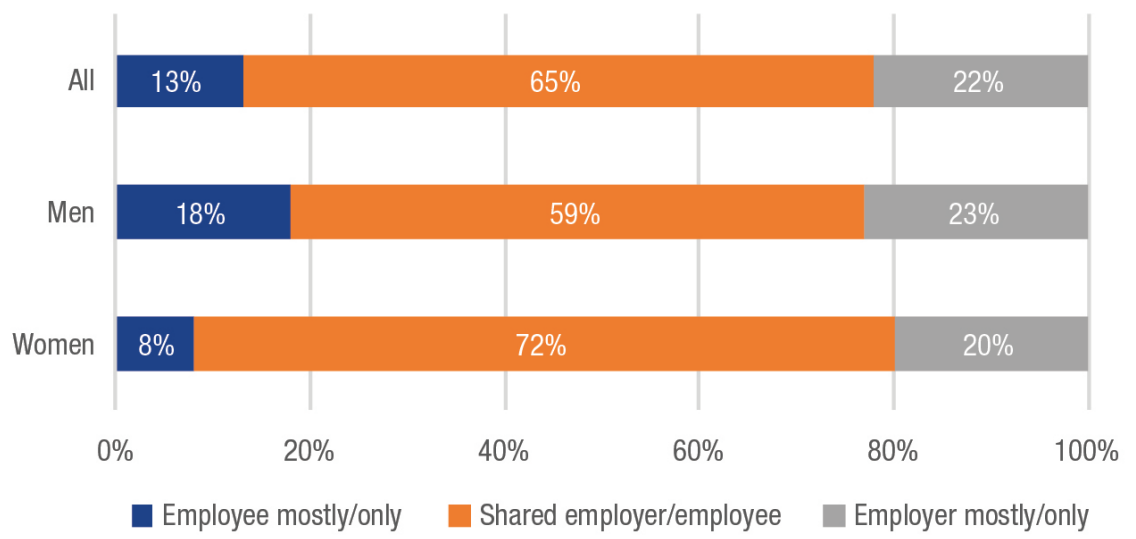

Note: Statistically significant difference between shared employer/employee by sex at $p>.05$. Source: Granite State Poll, Paid Family and Medical Leave Topical Module, 2018.

on research showing that workers were not taking leave because the replacement rate was too low. ${ }^{16}$ In an effort to encourage lower-wage workers to participate in their paid leave programs once up and running, legislation in Washington and Massachusetts includes wage reimbursement rates on a sliding scale. Washington will have a replacement rate of 90 percent for the lowestpaid workers, while Massachusetts' replacement rate will be 80 percent for the lowest-paid workers and an average of about 60-66 percent for everyone else.

\section{Who Pays the Premium?}

Some states, recognizing that both workers and businesses benefit from employees' access to paid leave, share program costs between employers and employees. For example, in New Jersey, New York, Washington, and Massachusetts, workers and employers share premium costs for coverage of workers' paid leave to tend to their own health care, but for family care workers pay the entire premium cost. The FAMILY Act includes 


\section{Data}

The data used in this analysis were collected in the Granite State Poll (GSP) in October 2018. The GSP, a random-digit-dialing telephone survey administered by the University of New Hampshire Survey Center, provides a statewide representative sample of approximately 500 households and collects demographic, economic, and employment information. The author developed a Paid Leave Topical Module that was added to the GSP. Employed respondents were asked to report on a battery of questions regarding access to paid and unpaid leave available to them through their employers.

In this brief, I report on respondents' access to different types of paid leave and whether respondents answered "no" to (1) having paid leave to care for a newborn or adopted child, (2) having paid leave to care for a family member with a serious illness or injury, (3) having paid leave for themselves when they are seriously ill or injured, or (4) having paid short-term disability leave. The measure of lacking access to paid leave for own illness included not having paid leave for themselves when they are seriously ill and not having paid short-term disability leave. I also report lacking access to all of these paid leave benefits.

The following question was asked to measure support for job protection: "Would you support or oppose a guarantee that workers be able to return to their job after using paid family and medical leave?" Respondents were asked to clarify whether they strongly supported, somewhat supported, somewhat opposed, or strongly opposed. In this brief, support includes those who strongly or somewhat supported a guarantee that workers return to their jobs.

The question regarding the right wage replacement rate asked respondents: "One proposal would provide workers with 60 percent of their typical wages through a statewide fund. Do you think 60 percent of your typical wages is too high, too low, or just about the right amount?" The following question was asked to measure who should pay the premium cost: "If a paid family and medical leave program were created in New Hampshire, how do you believe it should it be funded?" Respondents were read the following responses: (1) from employees only, (2) mostly from employees, (3) from employees and employers about equally, (4) mostly from employers, and (5) from employers only. I report on those who said they believed it should be funded from employees mostly or only, shared equally by employees and employers, and from employers mostly and only. Respondents were allowed to respond that they didn't know or were not sure. I exclude these respondents from the analysis.

Data are not shown for respondents with missing data. All analyses are weighted using household-level weights provided by the University of New Hampshire Survey Center based on U.S. Census Bureau estimates of the New Hampshire population. Differences presented in the text are statistically significant at $\mathrm{p}<.05$.

\section{End not es}

1. National Partnership for Women \& Families, "The Family and Medical Insurance Leave (FAMILY) Act," Factsheet (Washington, DC: National Partnership, 2019).

2. PerryUndem and Bellweather Research, "Voters' Views on Paid Family + Medical Leave: Findings From a National Survey" (Washington, DC: National Partnership for Women \& Families, 2018).

3. Kristin Smith, "Over 80 Percent of New Hampshire Residents Support Paid Family and Medical Leave," Carsey Research Brief \#103 (Durham, NH: Carsey School of Public Policy, 2016).

4. The Bureau of Labor Statistics (in the National Compensation Survey, 2018) estimated that nationally 17 percent of workers have paid family leave and fewer than 40 percent have paid medical leave through their employers.

5. Suma Setty, Curtis Skinner, and Renée Wilson-Simmons, Protecting Workers, Nurturing Families:

Building an Inclusive Family Leave Insurance Program (New York, NY: National Center for Children in Poverty, Mailman School of Public Health, Columbia University, 2016), http://www.nccp.org/publications/ pub_1152.htm; Eileen Appelbaum and Ruth Milkman, "Leaves That Pay: Employer and Worker Experiences With Paid Family Leave in California” (Washington, DC: Center for Economic and Policy Research, 2011).

6. Bureau of Labor Statistics, “Table 32. Leave Benefits: Access, Private Industry Workers, March 2018," 2018, https:// www.bls.gov/ncs/ebs/benefits/2018/ ownership/civilian/table32a.pdf.

7. Bureau of Labor Statistics, “Table 16. Insurance Benefits: Access, Participation, and Take-up Rates, Civilian Workers, March 2018," 2018, https://www.bls. gov/ncs/ebs/benefits/2018/ownership/ civilian/table32a.pdf. 
8. Jacob Klerman, Kelly Daley, and Alyssa Pozniak, "Family and Medical Leave in 2012: Technical Report" (Cambridge, MA: Abt. Associates, 2012), https://www.dol.gov/asp/ evaluation/fmla/FMLA-2012-Technical-Report.pdf; Setty et al., 2016; Appelbaum and Milkman, 2011.

9. Ariel Pihl and Gaetano Basso, "Paid Family Leave, Job Protection, and Low Take Up Among Low-Wage Workers" (University of California, Davis, no date); Fredrick Andersson, Henry Holzer, and Julia Lane, "Moving Up or Moving On: Who Gets Ahead in the Low-Wage Labor Market?" (New York, Russell Sage, 2005); Klerman et al., 2012.

10. Data not shown; however, all groups reported support for job protection at 90 percent or higher.

11. Maya Rossin-Slater, Christopher Ruhm, and Jane Waldfogel, “The Effects of California's Paid Family Leave Program on Mothers' Leave-Taking and Subsequent Labor Market Outcomes." Journal of Policy Analysis and Management, 32(2): 224-245, 2013; Charles Baum and Christopher Ruhm, "The Effects of Paid Family Leave in California on Labor Market Outcomes." Journal of Policy Analysis and Management, 35(2): 333-356, 2016.

12. Rosin-Slater et al., 2013.

13. Setty et al., 2016; Sarah Fass, "Paid Leave in the States: A Critical Support for Low-Wage Workers and Their Families" (New York, NY: National Center for Children in Poverty, Mailman School of Public Health, Columbia University, 2009); Appelbaum and Milkman, 2011.

14. Data are not shown by earnings quartiles due to some very small sample cells in the less than $60 \%$ wage replacement category.

15. Author analysis of 2018 Current Population Survey data finds about 15 percent of wage and salary workers earned $\$ 10$ or less per hour in 2017 (this calculation is derived by dividing workers' reported annual salary in the previous year by the product of their reported usual hours worked last year multiplied by the number of weeks worked last year).

16. Appelbaum and Milkman, 2011.

17. PerryUndem and Bellweather Research, 2018.

18. Differences in opinions of who should pay are not statistically significant by earnings quartile or by firm size.

\section{About the Author}

Kristin Smith is a family demographer at the Carsey School of Public Policy and research associate professor of sociology at the University of New Hampshire (kristin.smith@unh.edu).

\section{A cknow ledgments}

The National Partnership for Women \& Families provided support for the analysis and writing of this brief, the Carsey School of Public Policy provided support to produce it, and the Washington Center for Equitable Growth provided support for data collection. The author thanks Melissa Day for research assistance and Michael Ettlinger, Curt Grimm, Michele Dillon, Marybeth Mattingly, Laurel Lloyd, and Bianca Nicolosi at the Carsey School of Public Policy; Vicki Shabo at the National Partnership for Women \& Families; Christina D'Allesandro at MomsRising; and Patrick Watson for substantive comments and editorial assistance.

\section{University of New Hampshire Carsey School of Public Policy}

The Carsey School of Public Policy at the University of New Hampshire is nationally recognized for its research, policy education, and engagement. The school takes on the pressing issues of the twenty-first century, striving for innovative, responsive, and equitable solutions.

Huddleston Hall • 73 Main Street • Durham, NH 03824

(603) 862-2821

TTY UsERS: DIAL 7-1-1 OR 1-800-735-2964 (RELAY N.H.)

carsey.unh.edu 